\title{
THE EFFECTS OF ANTIDEPRESSANT THERAPY ON HEALTH-RELATED QUALITY OF LIFE IN PATIENTS WITH A CHRONIC OBSTRUCTIVE PULMONARY DISEASE AND DEPRESSIVE SYMPTOMS
}

Ivana Jelic $^{1}$, Marko Folic ${ }^{1,2}$, Filip Mihajlovic ${ }^{1}$, Slobodan Jankovic ${ }^{1,2}$ and Goran Mihajlovic ${ }^{1,3}$

${ }^{I}$ Faculty of Medical Sciences, University of Kragujevac, Kragujevac, Serbia

${ }^{2}$ Clinical Pharmacology Department, University Clinical Centre Kragujevac, Kragujevac, Serbia

${ }^{3}$ Psychiatry Clinic, University Clinical Centre Kragujevac, Kragujevac, Serbia

\section{EFIKASNOST TERAPIJE ANTIDEPRESIVA NA KVALITET ŽIVOTA PACIJENATA SA HRONIČNOM OPSTRUKTIVNOM BOLEŠĆU PLUĆA I SIMPTOMIMA DEPRESIJE}

\author{
Ivana Jelić ${ }^{1}$, Marko Folić ${ }^{1,2}$, Filip Mihajlović ${ }^{1}$, Slobodan Janković1 ${ }^{1,2}$ i Goran Mihajlovic $^{1,3}$ \\ ${ }^{1}$ Fakultet medicinskih nauka, Univerzitet u Kragujevcu, Kragujevac, Srbija \\ ${ }^{2}$ Klinika za farmakologiju, Univerzitetski Klinički centar Kragujevac, Kragujevac, Srbija \\ ${ }^{3}$ Klinika za prihijatriju, Univerzitetski Klinički centar Kragujevac, Kragujevac, Srbija
}

\begin{abstract}
Background. Symptoms of depression are often present in patients with chronic obstructive pulmonary disease (COPD) and treatment of depression may substantially improve the quality of life of such patients. The aim of our study was to investigate factors that influence the efficacy of antidepressant therapy in terms of the quality of life in patients with COPD and a depressive disorder.
\end{abstract}

Materials and Methods. The study was designed as a prospective cross-sectional study and conducted between October 2016 and December 2019 in the Primary Health Center, Kragujevac, Serbia. The study sample included 87 patients. Associations between putative risk factors and change in the quality-of-life score were tested by a multivariate linear regression model and interpreted by the regression coefficients.

Results. Our study showed a clear positive effect of therapy with SSRIs on the severity of depression symptoms and the quality of life of patients with co-occurrence of COPD and depression. However, multiple linear regression shows that the effect of SSRIs was more prominent in patients with a higher degree of COPD severity since patients with lower $F E V_{I}$ values had a more extensive increase in the $Q-L E S-Q-S F$ score $(B=-0,034$; $p=0,020)$.

Conclusion. Treatment of depression that accompanies COPD is an important segment of managing such patients, which significantly improves HRQoL. Patients with more severe COPD would especially benefit from such treatment since their response to SSRIs is more pronounced.

Keywords: Chronic obstructive pulmonary disease; depression; antidepressants; quality of life.

\section{SAŽETAK}

Uvod. Simptomi depresije su često prisutni kod pacijenata sa hroničnom opstruktivnom plućnom bolešću (HOBP), a lečenje depresije može značajno poboljšati kvalitet života takvih pacijenata. Cilj našeg istraživanja bio je da se ispitaju faktori koji utiču na efikasnost terapije antidepresivima u smislu kvaliteta života pacijenata sa $H O B P$ i depresivnim poremećajem.

Materijal i metode. Studija je osmišljena kao prospektivna presečna studija i sprovedena je u periodu od oktobra 2016. do decembra 2019. u Domu zdravlja, Kragujevac, Srbija. Uzorak studije uključivao je 87 pacijenata. Povezanost između pretpostavljenih faktora rizika i promene u oceni kvaliteta života testirana je multivarijantnim linearnim regresionim modelom i tumačena regresionim koeficijentima.

Rezultati. Naša studija pokazala je jasan pozitivan efekat terapije SSRI-ima na ozbiljnost simptoma depresije i kvalitet života pacijenata sa istovremenom pojavom HOBP-a i depresije. Međutim, višestruka linearna regresija pokazuje da je efekat SSRI-a bio izraženiji kod pacijenata sa većim stepenom težine HOBP budući da su pacijenti sa nižim vrednostima FEV1 imali opsežniji porast $Q-L E S-Q-S F$ skora $(B=-0,034 ; p=0,020)$.

Zaključak. Lečenje depresije koja prati HOBP važan je segment u praćenju simptoma takvih pacijenata, što značajno poboljšava HRQoL. Pacijenti sa težom HOBP bi imali posebnu korist od takvog tretmana jer je njihov odgovor na SSRI izraženiji

Ključne reči: hronična opstruktivna bolest pluća, depresija, antidepresivi, kvalitet života. 


\section{INTRODUCTION}

Chronic obstructive pulmonary disease (COPD) is a progressive lung disease and is the third leading cause of death worldwide [1]. COPD adversely affects the quality of life of patients, decreasing the number of Disability Adjusted Life Years (DALY) one can get during lifetime [2]. A number of countries organized national registries of COPD patients, showing a relatively high prevalence of this disease, which ranges between 4 and 5\% [3-5]. Numerous factors contribute to the development of COPD. Long-term tobacco smoking associated with outdoor, occupational and indoor air pollution and genetic predisposition is one of the main factors contributing to the development of obstructive pulmonary disease $[1,2,6]$. The severity of COPD also depends on the age and sex of the patient, frequency of exacerbations, clinical picture, and results of diagnostic procedures $[2,7]$.

There are many other serious diseases and chronic medical conditions that may co-occur in individuals with COPD. Symptoms of depression are often present in COPD patients, with prevalence of $15,2 \%$ to $35,7 \%$ [8]. However, it is difficult to distinguish between true depression and the depressive reaction of COPD patients, because COPD itself affects some basic life functions and roles. A lot of mental and physical symptoms are related to both disorders: increased fatigue, sleep and appetite disorders, reduced physical activity, difficulty with concentration $[9,10]$. People with depression also smoke more often and more intensely, further aggravating COPD. Depression in patients with COPD further reduces their working ability as well as the quality of life [11]. Several studies showed that some respiratory and physical symptoms were directly related to depression symptoms in patients with COPD $[12,13]$.

The aim of our study was to investigate the factors that influence the efficacy of antidepressant therapy in terms of the quality of life in patients with COPD and a depressive disorder.

\section{MATERIAL AND METODS}

The study was set up as a prospective cross-sectional study and conducted between October 2016 and December 2019 in the Primary Health Center, Kragujevac, Serbia. The inclusion criteria were adulthood, diagnosis of COPD established by a specialist of pulmonology and diagnosis of any type of depression by a specialist of psychiatry. The exclusion criteria were pregnancy and co-morbid malignant diseases. A diagnosis of COPD was established on medical history, current symptoms, suggestive findings from physical examination, and available pulmonary function tests, as per the definitions provided by GOLD criteria. The estimate of COPD severity was based on the post-bronchodilator forced expiratory volume in the $1^{\text {st }}$ second $\left(\mathrm{FEV}_{1}\right)$. The study sample included 87 patients. The study was approved by the Institutional Ethical Review Board and Ethics Committee of the Primary Health Center, Kragujevac, Serbia (No: 01$542 / 2,2016)$

The severity of depression in the study patients was evaluated by the Hamilton Scale (HAM-D), and healthrelated quality of life was assessed by short form of the Quality of Life Enjoyment and Satisfaction Questionnaire (Q-LES-Q-SF) [14-16]. The evaluations were made before and after 8 weeks of treatment with selective serotonin reuptake inhibitors (SSRIs) administered according to the preference of psychiatrists who treated the patients. The data about demography, habits, concomitant diseases and concomitant therapy were extracted from the patient files.

The data were described by descriptive statistics, using measures of central tendency (mean or median), variability (standard deviation from the mean) and relative numbers. The differences in the values of continuous variables in the same patients at the beginning and the end of the study were tested by Wilcoxon signed rank test, or by Friedman's test, where applicable.

The differences were considered significant if the probability of the null hypothesis was $\leq 0.05$. Associations between putative risk factors and change in the quality of life score were tested by a multivariate linear regression model, and interpreted by the regression coefficients. Previously it was tested whether the data met assumptions for linear regression (linear relationship, homoscedasticity, nomulticollinearity and normal distribution of residuals). All calculations were performed by the SPSS (Statistical Package for Social Science for Windows) software, version 18.

\section{RESULTS}

Characteristics of the study group are shown in Table 1, as well as changes in HAM-D scale score and Q-LES-Q-SF score from basal to values after 8 weeks of therapy. Both scores showed statistically significant improvement after 8week therapy with SSRIs. Patients' overall satisfaction with the treatment and life, in general, were rated with questions 15 and 16 of the Q-LES-Q-SF scale. Friedman's test showed that ratings of both questions significantly improved after treatment with the SSRIs: $(\mathrm{Fr}=15.00, \mathrm{df}=1, \mathrm{p}<0.001)$ and $(\mathrm{Fr}=78.00, \mathrm{df}=1, \mathrm{p}<0.001)$, respectively. 


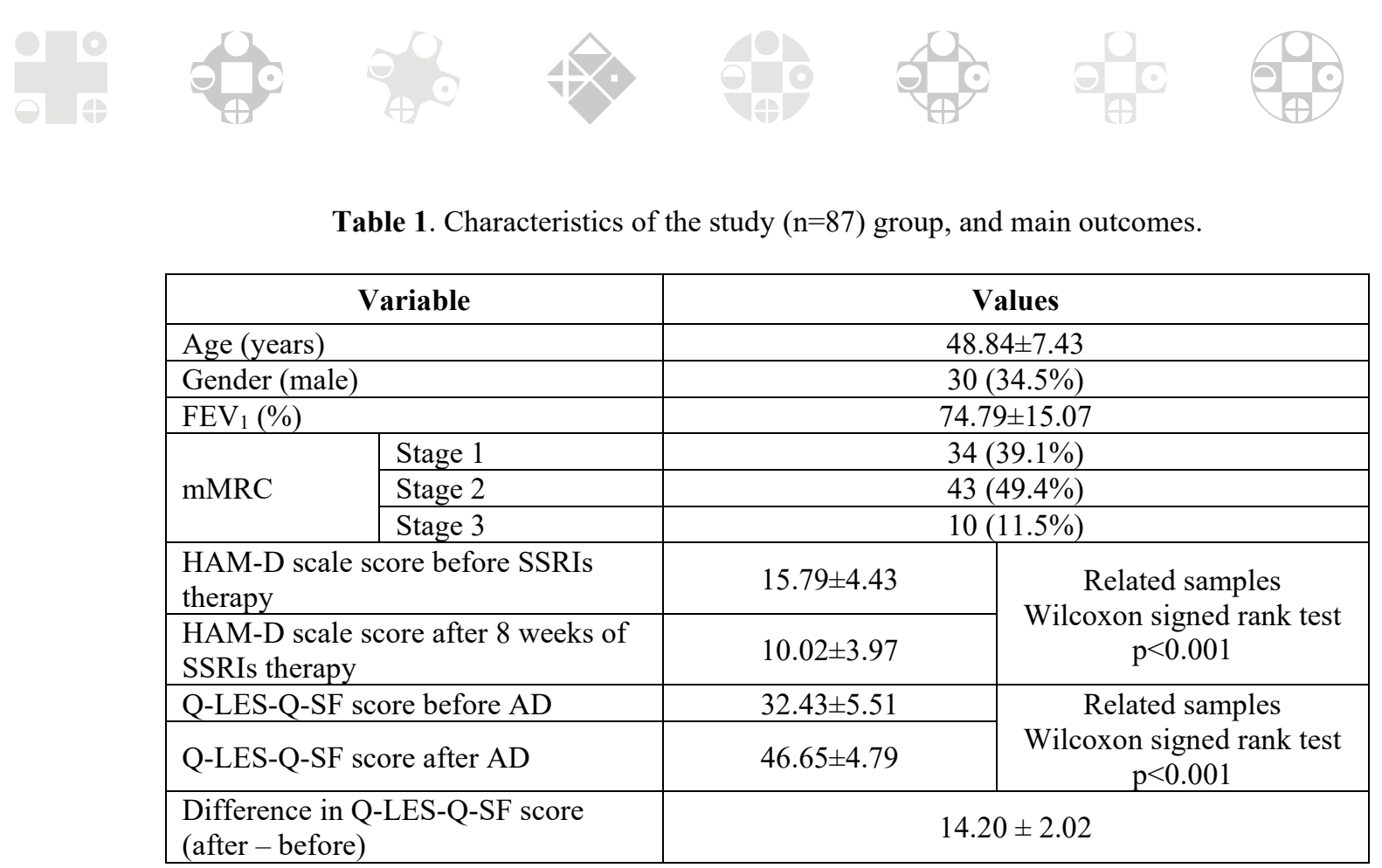

A multiple linear regression model was built including the following predictors of difference between values of the QLES-Q-SF score after and before the treatment with SSRIs: gender, age, mMRC, FEV 1 , HAM-D scale scores before and after 8 weeks of SSRI therapy. The only significant predictor turned out to be the $\operatorname{FEV}_{1}(\mathrm{p}=0,020)($ Table 2$)$.

Table 2. Significant predictor of difference between values of the Q-LES-Q-SF score after and before the treatment with SSRIs.

\begin{tabular}{|c|c|c|c|c|c|c|c|}
\hline Predictor & $\begin{array}{c}\text { Adjusted } \\
\mathrm{R}^{2}\end{array}$ & $\mathrm{~F}$ & $\mathrm{~B}$ & $\mathrm{t}$ & $\mathrm{p}$ & \multicolumn{2}{|c|}{$\begin{array}{c}95,0 \% \text { Confidence } \\
\text { Interval for B }\end{array}$} \\
\hline $\mathrm{FEV}_{1}$ & 0.051 & $\begin{array}{c}5.625 \\
(\mathrm{p}=0.020)\end{array}$ & -0.034 & -2.372 & 0.020 & -0.062 & -0.005 \\
\hline
\end{tabular}

\section{DISCUSSION}

Our study showed a clear positive effect of therapy with SSRIs on both severity of depression symptoms and the quality of life of patients with co-occurrence of COPD and depression. However, the effect of SSRIs is more prominent in patients with a higher degree of COPD severity, since patients with lower $\mathrm{FEV}_{1}$ values had a more extensive increase in the Q-LES-Q-SF score.

Inverse correlation between the severity of COPD and health-related quality of life (HRQoL) was shown in many studies: dyspnea, nocturnal symptoms, reduced physical activity, and frequent exacerbations affect adversely physical, psychological and social aspects of a patient's life [17]. More severe symptoms result in lower quality of life, and vice versa. On the other hand, it is well known that patients with worse depression have more visible improvement after a period of treatment with antidepressant medication, because their baseline was lower in the beginning and maximal therapeutic response cannot be pushed further [18]. This effect was first proven for tricyclic antidepressants, and then shown also for SSRIs. It seems that the same holds true for other types of antidepressants, including noradrenaline reuptake inhibitors (NARIs) like reboxetine [19]. Our results speak in favor of the fact that improvement in depressive symptoms is more pronounced in patients with more severe COPD; this underlines the necessity to recognize early symptoms of depression in patients with COPD and implement treatment with SSRIs or other antidepressants.

Adherence to prescribed medication is crucial for the beneficial outcome of treatment in COPD patients [20]. Since the adherence is improved if the patients are less depressive and anxious [21], if depressive symptoms are recognized early in a patient with COPD, and treatment with SSRIs started without delay, the patients will be more adherent to prescribed bronchodilators and other COPD medication, with resultant improved outcome. Improved COPD would then additionally help with the decrease of symptoms of depression, and a beneficial circle will be established, resulting in the end with minimized COPD symptoms and maximized quality of life. 
There are certain limitations of our study. In the first place, our study was based on a non-randomized sample, which may introduce a certain degree of selection bias. Second, the size of the sample was relatively small, so only the factor with really strong statistical influence could have been delimited as significant (severity of COPD), while a number of also important factors were subject to type two statistical error.

In conclusion, our study showed that treatment of depression that accompanies COPD is an important segment of managing such patients, which significantly improves HRQoL. The patients with more severe COPD would especially benefit from such treatment since their response to SSRIs is more pronounced.

\section{DISCLOSURE STATEMENT}

None of the authors has any conflict of interest regarding the content of this manuscript.

\section{AUTHOR CONTRIBUTIONS}

I.J., F.M. and G.M. contributed to the concept and design of the study and collected data. M.F. and S.M. participated in the study design, analyzed and interpreted data and wrote the manuscript.

Each author listed on the manuscript has seen and approved the submission of this version of the manuscript.

\section{REFERENCES}

1. WHO. Chronic obstructive pulmonary disease (COPD). Available at https://www.who.int/news-room/factsheets/detail/chronic-obstructive-pulmonary - disease(copd) Published June 21, 2021. Accessed: July 24, 2021.

2. Global Initiative for Chronic Obstructive Lung Disease (GOLD). Global Strategy for the Diagnosis, Management and Prevention of Chronic Obstructive Pulmonary Disease: $2021 \quad$ Report. Available https:/ /goldcopd.org/wp-content/uploads/2020/11/GOLD-RE PORT-2021-v1.1-25Nov20_WMV.pdf. Accessed: July 26, 2021.

3. Lazic Z, Stankovic I, Milenkovic B, Zvezdin B, Hromis S, Jankovic S, et al. Characteristics of COPD Phenotypes in Serbia. Int $\mathrm{J}$ Chron Obstruct Pulmon Dis. 2021;16:643-54.

4. Nagorni-Obradovic LM, Vukovic DS. The prevalence of COPD co-morbidities in Serbia: results of a national survey. NPJ Prim Care Respir Med. 2014;24:14008.

5. Vukoja M, Kopitovic I, Lazic, Z, Milenkovic B, Stankovic I, Zvezdin B et al. Diagnosis and management of chronic obstructive pulmonary disease in Serbia: an expert group position statement. Int J Chron Obstruct Pulmon Dis. 2019;14:1993-2002.

6. Eisner MD, Anthonisen N, Coultas D, Kuenzli N, PerezPadilla R, Postma D, et al; Committee on Nonsmoking
COPD, Environmental and Occupational Health Assembly. An official American Thoracic Society public policy statement: Novel risk factors and the global burden of chronic obstructive pulmonary disease. Am J Respir Crit Care Med. 2010;182(5):693-718.

7. Montserrat-Capdevila J, Godoy P, Marsal JR, Barbé F, Galván L. Risk of exacerbation in chronic obstructive pulmonary disease: a primary care retrospective cohort study BMC Family

Practice. 2015;16:173.

8. Matte DL, Pizzichini MM, Hoepers AT, Diaz AP, Karloh M, Dias M, et al. Prevalence of depression in COPD: A systematic review and meta-analysis of controlled studies. Respir Med. 2016;117:154-61.

9. von Haehling S, Anker SD. Cachexia as major underestimated unmet medical need: facts and numbers. Int J Cardiol. 2012;161(3):121-3.

10. Schols AM, Soeters PB, Dingemans AM, Mostert R, Frantzen PJ, Wouters EF. Prevalence and characteristics of nutritional depletion in patients with stable COPD eligible for pulmonary rehabilitation. Am Rev Respir Dis. 1993;147(5):1151-6.

11. Blakemore A, Dickens C, Guthrie E, Bower P, Kontopantelis E, Afzal C, et al. Depression and anxiety predict health-related quality of life in chronic obstructive pulmonary disease: systematic review and meta-analysis. Int $\mathrm{J}$ Chron Obstruct Pulmon Dis. 2014;9:501-12.

12. Sundh J, Ekström M. Persistent disabling breathlessness in chronic obstructive pulmonary disease. Int J COPD. 2016;11(1):2805-12.

13. Regvat J, Žmitek A, Vegnuti M, Košnik M, Šuškovič S. Anxiety and depression during hospital treatment of exacerbation of chronic obstructive pulmonary disease. J Int Med Res. 2011;39(3):1028-38.

14. Hamilton M. A rating scale for depression. J Neurol Neurosurg Psychiatry. 1960;23(1):56-62.

15. Trajković G, Starčević V, Latas M, Leštarević M, Ille T, Bukumirić Z, et al. Reliability of the Hamilton Rating Scale for Depression: A meta-analysis over a period of 49 years. Psychiatry Research, 2011;189(1): $1-9$.

16. 16. Endicott J, Nee J, Harrison W, Blumenthal R. Quality of Life Enjoyment and Satisfaction Questionna ire: A New Measure. Psychopharmacology Bulletin 1993;29:321-6

17. Contoli M, Solidoro P, Di Marco F, Scichilone N, Corsico A, Braido F, et al. Effects of aclidinium on determinants of COPD severity: symptoms and quality of life. Int J Chron Obstruct Pulmon Dis. 2016;11:30 43-50.

18. Khan A, Brodhead AE, Kolts RL, Brown WA. Severity of depressive symptoms and response to antidepressants and placebo in antidepressant trials. J Psychiatr Res. 2005;39(2):145-50.

19. Wiles NJ, Mulligan J, Peters TJ, Cowen PJ, Mason V, Nutt D, et al. Severity of depression and response to antidepressants: GENPOD randomised controlled trial. Br J Psychiatry. 2012;200(2):130-6. 
20. Rogliani P, Ora J, Puxeddu E, Matera MG, Cazzola M. Adherence to COPD treatment: Myth and reality. Respir Med. 2017;129:117-23.

21. Fan VS, Giardino ND, Blough DK, Kaplan RM, Ramsey SD; Nett Research Group. Costs of pulmonary reha bilitation and predictors of adherence in the National Emphysema Treatment Trial. COPD. 2008;5(2):105-16. 